\title{
Catalytic transesterification of dialkyl phosphates by a bioinspired dicopper(II) macrocyclic complex.
}

Malgorzata Jagoda,$^{\dagger}$ Sabine Warzeska, ${ }^{\dagger}$ Hans Pritzkow, ${ }^{\dagger}$ Hubert Wadepohl, ${ }^{\dagger}$ Petra Imhof, ${ }^{\ddagger}$ Jeremy Smith, ${ }^{\ddagger}$ Roland Kraemer* ${ }^{\dagger}$

\section{Supporting Information}

Spectrophotometric Titration of $\mathbf{L}$ with $\mathbf{Z n}$. A solution of $\mathbf{L}(100 \mu \mathrm{M})$ was prepared in methanol/chloroform $(9: 1 \mathrm{v} / \mathrm{v})$. Aliquots of stock solutions containing $\mathrm{Zn}\left(\mathrm{NO}_{3}\right)_{2} \cdot 4 \mathrm{H}_{2} \mathrm{O}(20$ $\mathrm{mM}$ in methanol/chloroform; 9:1 v/v) were added with stirring. Immediately after addition, a UV spectrum of the solution was taken at $25^{\circ} \mathrm{C}$. A volume correction of absorbance was not performed since total volume of added $\mathrm{Zn}\left(\mathrm{NO}_{3}\right)_{2} \cdot 4 \mathrm{H}_{2} \mathrm{O}$ do not exceed $2 \%$ of the reaction solution.
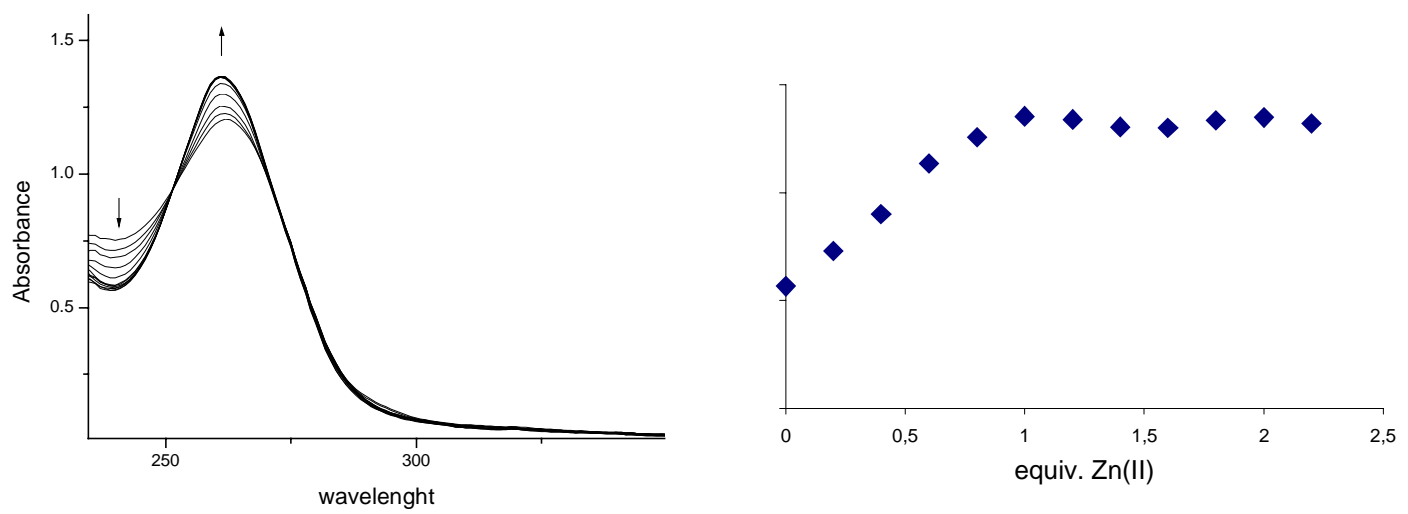

Figure 1. Left : spectrophotometric titration of $\mathbf{L}(0.1 \mathrm{mM})$ in methanol-chloroform $(9: 1$; in 0.2 equiv. steps) with $\mathrm{Zn}\left(\mathrm{NO}_{3}\right)_{2} \cdot 4 \mathrm{H}_{2} \mathrm{O}$. Right: absorbance diagram at $265 \mathrm{~nm}$ for addition of $0-2.2$ equiv. $\mathbf{Z n}(\mathrm{II})$ to $\mathbf{L}$. 
Dependence of initial rate of DMP cleavage on catalyst concentration. In a typical kinetic assay, $7.4 \mathrm{mg}(50 \mu \mathrm{mol})$ sodium dimethyl phosphate was added to $1 \mathrm{~mL}$ of a stock solution of 1 ( $1-3 \mathrm{mM}$ ) in $\mathrm{CD}_{3} \mathrm{OD}$ and the solution transferred to an NMR tube. The sample was kept at $55^{\circ} \mathrm{C}$, and ${ }^{1} \mathrm{H}$ NMR spectra were recorded in appropriate time intervals. Conversion of $\mathrm{O}_{2} \mathrm{P}\left(\mathrm{OCH}_{3}\right)_{2}^{-}$to $\mathrm{O}_{2} \mathrm{P}\left(\mathrm{OCH}_{3}\right)\left(\mathrm{OCD}_{3}\right)^{-}$was followed by integration of the signals of released methanol and residual methyl ester.

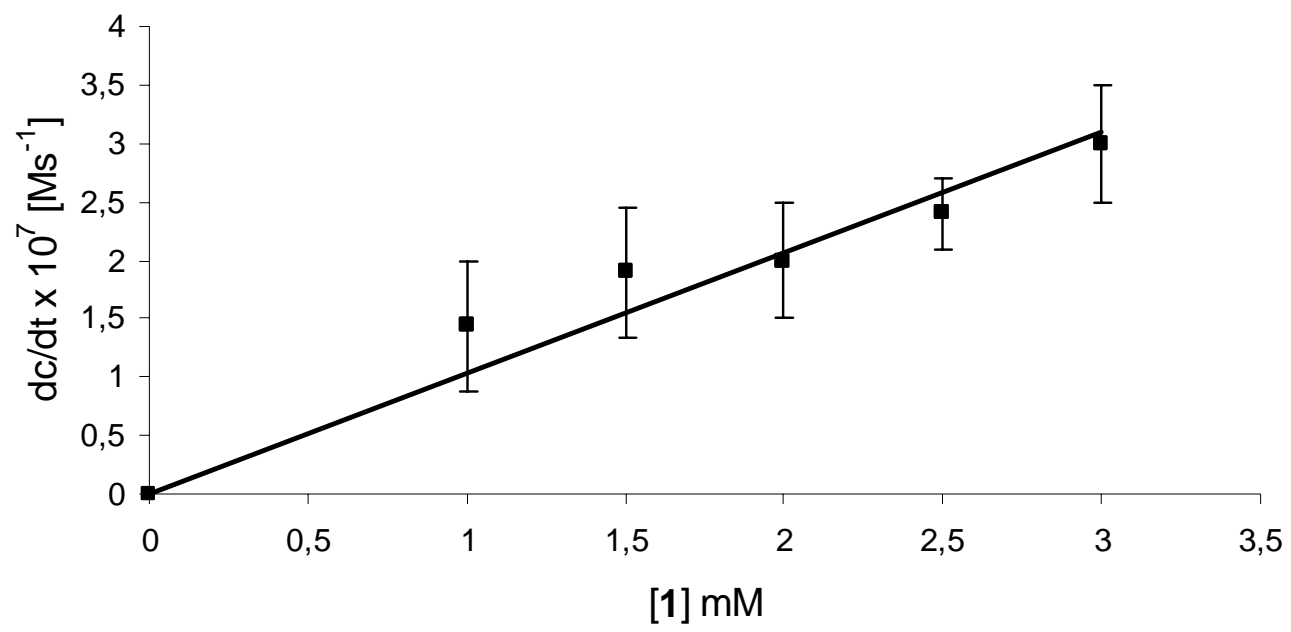

Figure 2. Dependence of initial rate $(\mathrm{dc} / \mathrm{dt})$ at $55^{\circ} \mathrm{C}$ of DMP $(50 \mathrm{mM})$ cleavage in $\mathrm{CD}_{3} \mathrm{OD}$ on concentration of 1 . The ${ }_{s}^{\mathrm{s}} \mathrm{pD}$ value of the $\mathrm{CD}_{3} \mathrm{OD}$ solution at $25^{\circ} \mathrm{C}$ was $9.9 \pm 0.2$, adjusted by addition of $p$-toluonesulfonic acid to the solution at 1 and $1.5 \mathrm{mM} 1$ (pH meter reading of the $\mathrm{CD}_{3} \mathrm{OD}$ solution, correction value 2.24 added). 
Saturation kinetics for the hydrolysis of DMP by 1. In a typical kinetic assay, appropriate amount of sodium dimethyl phosphate ( $0.1 \mathrm{M}$ stock solution in $\mathrm{CD}_{3} \mathrm{OD}$ ) was added to $1 \mathrm{~mL}$ of a $2 \mathrm{mM}$ stock solution of $\mathbf{1}$ in $\mathrm{CD}_{3} \mathrm{OD}$ and the solution transferred to an NMR tube. The sample was kept at $55^{\circ} \mathrm{C}$, and ${ }^{1} \mathrm{H}$ NMR spectra were recorded in appropriate time intervals. Conversion of $\mathrm{O}_{2} \mathrm{P}\left(\mathrm{OCH}_{3}\right)_{2}{ }^{-}$to $\mathrm{O}_{2} \mathrm{P}\left(\mathrm{OCH}_{3}\right)\left(\mathrm{OCD}_{3}\right)^{-}$was followed by integration of the signals of released methanol and residual methyl ester.

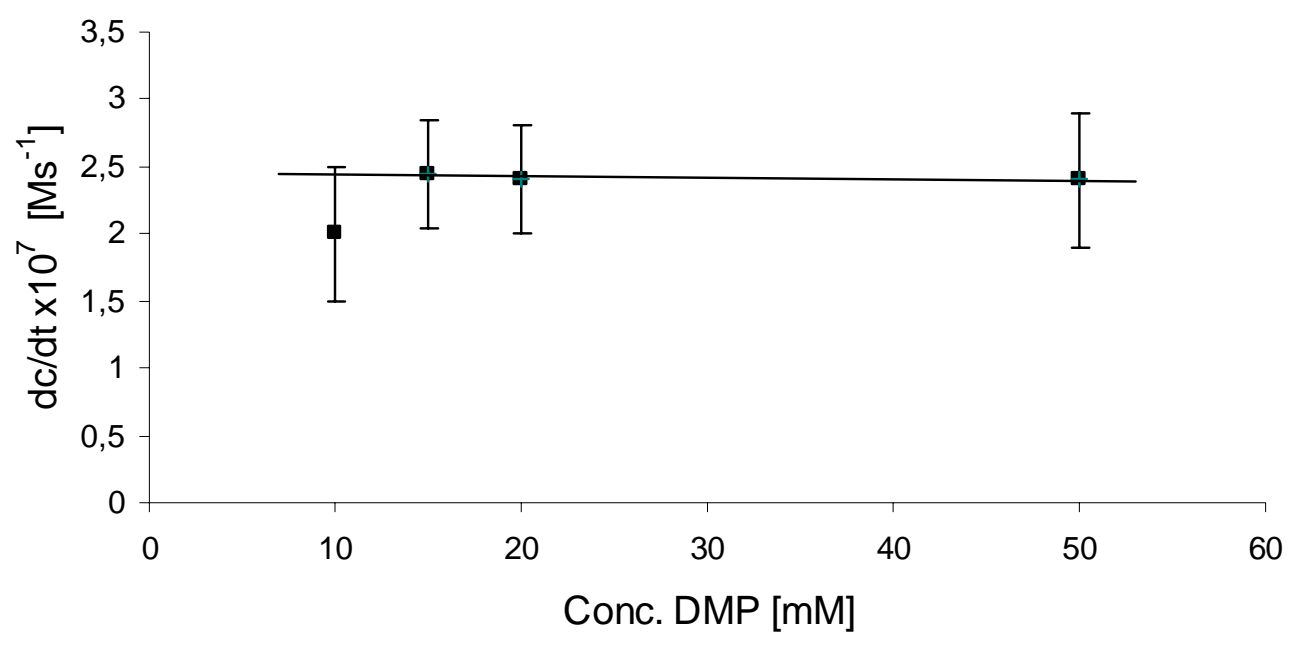

Figure 3. Hydrolysis of DMP (varying concentrations) by $1(2 \mathrm{mM})$ in $\mathrm{CD}_{3} \mathrm{OD}$ at $55^{\circ} \mathrm{C}$. $\mathrm{k}_{\text {cat }}$ $=1.2 \cdot 10^{-4} \mathrm{~s}^{-1}$ was obtained by dividing dc/dt max by [1]. The ${ }_{\mathrm{s}}^{\mathrm{s}} \mathrm{pD}$ of the solution was $9.9 \pm$ 0.3 at $25^{\circ} \mathrm{C}\left(\mathrm{pH}\right.$ meter reading of the $\mathrm{CD}_{3} \mathrm{OD}$ solution, correction value 2.24 added). The $\mathrm{pD}$ of the solution dropped to $<9.5$ when $[\mathrm{DMP}]<10 \mathrm{mM}$, therefore data at $<10 \mathrm{mM}$ DMP were not included. 
pH titration of $1+\mathrm{NaDMP}(\mathbf{1 : 1})$ in $\mathrm{CH}_{3} \mathrm{OH}$. A solution of $\mathbf{1}+\mathrm{NaDMP}(1 \mathrm{mM}$ each) is prepared in methanol. Aliquots of $\mathrm{CO}_{2}$-free $\mathrm{NaOCH}_{3}$ stock solution (100 mM in methanol) were added with stirring. $\mathrm{pH}$ meter reading was stable after about $30 \mathrm{~s}$ equilibration time. The recommended ${ }^{1}$ correction value 2.24 was added to the $\mathrm{pH}$ meter reading to obtain ${ }_{\mathrm{s}}^{\mathrm{s}} \mathrm{pH}$. For comparison, a solution of $\mathrm{CH}_{3} \mathrm{CO}_{2} \mathrm{H}(1 \mathrm{mM})$ is titrated with $\mathrm{NaOCH}_{3}$.

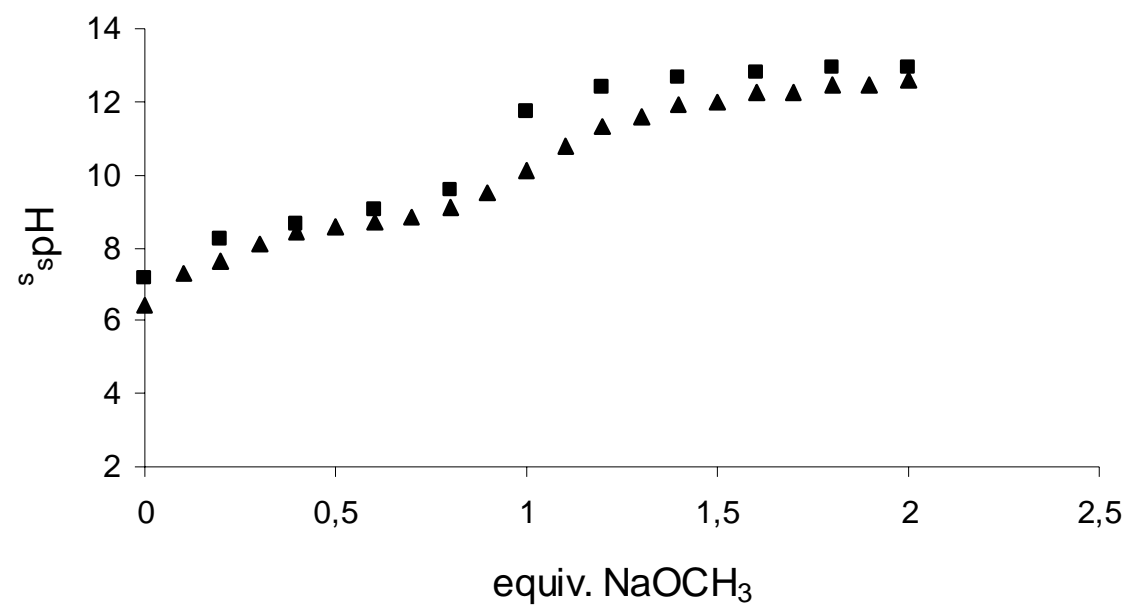

Figure 4. $\mathrm{pH}$ titration in methanol of $\mathbf{1} / \mathrm{NaDMP}(1: 1, \boldsymbol{\Delta})$ and $\mathrm{CH}_{3} \mathrm{COOH}(\boldsymbol{\square}),(1 \mathrm{mM}$ each) with $\mathrm{NaOCH}_{3} . \mathrm{T}=25^{\circ} \mathrm{C}$

\section{Refrences}

1. Bosch, E.; Rived, F.; Roses, M.; Sales, J., J. Chem. Soc. Perkin Trans. 2, 1999, 1953-1958 